\title{
Tourism Sector Competitiveness in Portugal: applying Porter's Diamond
}

\section{A competitividade do setor do turismo em Portugal: aplicando o diamante de Porter}

\author{
Cristina Estevão \\ Instituto Politécnico de Castelo Branco - Escola Superior de Gestão, Largo do Município 6060-163 Idanha-a-Nova, Portugal, \\ cristina.estevao@ipcb.pt
}

Sara Nunes

Instituto Politécnico de Castelo Branco - Escola Superior de Gestão, Portugal, sara@ipcb.pt

\author{
João Ferreira \\ Universidade da Beira Interior, Department of Management and Economics, R. Marquês de Ávila e Bolama, 6201-001 Covilhã, \\ Portugal, jjmf@ubi.pt
}

Cristina Fernandes

Instituto Politécnico de Castelo Branco - Escola Superior de Gestão, Portugal, cristina.fernandes@ipcb.pt

\begin{abstract}
The tourism sector has stood out for its enormous capacity for growth on a global scale and holding a relevant role both as a tool for the competitiveness and as a driver of regional development. This profile stems not only from its multiplier effects but also the opportunities susceptible to identification within the scope of offsetting regional disparities in growth and prosperity. The objective of this research consists of evaluating the competitiveness of the regional areas and directorates of tourism in Portugal. We have used primary data (a sample of 446 companies), through a questionnaire aimed at companies displaying the activities characteristic of the World Tourism Organisation satellite account. Through the application of Porter's Diamond Model, we attained at a conceptual model through recourse to the Partial Least Square - Path Modelling technique with the objective of analysing the relationships unfolding among the determinant variables to competitiveness in the tourism sector. Despite the results returned proving clear, we also verify that encapsulating competitiveness proves no easy task given how Portugal reports regions with simultaneously very varied and very specific characteristics.
\end{abstract}

Keywords: Tourism, competitiveness, Porter's diamond, regional tourism area, Portugal.

\section{Resumo}

O sector do turismo destaca-se pela enorme capacidade de crescimento a nível mundial, desempenhando um papel relevante tanto como ferramenta para a competitividade como enquanto motor do desenvolvimento regional. Este perfil decorre não apenas dos seus efeitos multiplicadores, mas também das oportunidades suscetíveis de identificação no âmbito da compensação das disparidades regionais no crescimento e prosperidade. O objetivo desta investigação consiste em avaliar a competitividade das áreas regionais e direções do turismo em Portugal. Utilizamos dados primários (uma amostra de 446 empresas), através de um questionário destinado a empresas que exibem as atividades características da conta satélite da Organização Mundial de Turismo. Através da aplicação do Modelo de Diamante de Porter, alcançamos um modelo conceitual através do recurso à técnica de Partial Least Square - Path Modelling com o objetivo de analisar as relações que se desdobram entre as variáveis determinantes para a competitividade no setor de turismo. Apesar de os resultados retornados serem claros, verificamos também que o encapsulamento da competitividade não se revela uma tarefa fácil, dado o fato de Portugal englobar regiões com características simultaneamente muito variadas e muito específicas.

Palavras-chave: Turismo, competitividade, diamante de Porter, área regional de turismo, Portugal.

\section{Introduction}

Tourism is a growing industry and expanding its importance not only in developed countries but also in their developing counterparts (Chao, Hazari, Laffargue, Sgro, \& Yu, 2005; SinclairMaragh \& Gursoy, 2015; Zaman Shahbaz, Loganathan, \& Raza, 2016), duly recognised as one of the most relevant of contemporary economic and social trends and driving a motor of economic growth with extremely significant national impacts (Sharpley, 2002; Chao et al., 2005). Additionally, whilst the importance of tourism at the national levels is clear, this sector provides an essential tool to development and economic growth at the regional level, identified as a "tool" for avoiding desertification and economic stagnation in regions, especially those located inland (Jackson, 2006). What is still furthermore, tourism also constitutes a prodigious source of creation of both value and employment (Botti, Camprubi, \& Torrès, 2008).
However, the success of tourism destinations in global markets gets influenced by relative competitiveness (Enright \& Newton, 2005). Thus, the competitiveness of tourism destination proves of increasing importance to countries seeking to control a larger proportion of the tourism market and of corresponding relevance to those who greatly depend on the tourism and travel industry sectors (Echtner \& Ritchie, 2003; Navickas \& Malakauskaite, 2009). Crouch and Ritchie (1999) and Dwyer and Kim (2003) unanimously affirm that the development of the tourism potential of any country or region depends substantially on its capacity to retain competitive advantages in the supply of goods and services to visitors and that the competitiveness of a tourism destination interrelates with its abilities to provide its tourists with goods and services better than the competition.

According to Navickas and Malakauskaite (2009), tourism competitiveness has been a fairly common target for study with 
many scientifically identifying and analysing development models and general theories of tourism destination competitiveness (Porter, 1990; Crouch \& Ritchie, 1999; Dwyer \& Kim, 2003; Malakauskaite \& Navickas, 2010), even while only a few studies empirically operationalise these models.

In keeping with the recent Law no. 33/2013 of 16 May, which established a new juridical regime for the regional tourism areas of mainland Portugal, including all of the areas making up the five units constituting the NUTS II level - the Nomenclature for Territorial Units for Statistical Purposes - and the only incipient research focused on the empirical validation of the models of competition applied to Portugal in general and its tourism regions in particular, it proves especially pertinent to study the factors contributing to the competitiveness of these destinations. Thus, the present research takes the following structure: we initially set out a theoretical framework regarding the importance of tourism to regional development and tourism competitiveness before going on to detail the geographic area of study as well as the methodology applied in the research. Finally, we present the analysis, discuss the results and their respective conclusions.

\section{Theoretical framework}

\subsection{Tourism as an actor in regional development}

Tourism gets ranked as one of the most important of all sectors worldwide with the literature returning a broad reaching consensus as to the core role played in the development and competitiveness of many regions (Alberti \& Giusti, 2012; Zhang, 2016). According to UNWTO (2015) the tourism annual turnover more than $\$ 3.5$ trillion and is also a sector the fastest growing in the world.

Regional development derives from the integration of the spatial variable into the study of development which thus appears bound up with a concrete spatial reference - the region (Alberto, 2008; Komppula, 2014). Throughout many years, the tourism sector would express regret that governments and populations in general systematically ignored its economic and social importance. However, these "oversights" have been corrected and governments have increasingly recognised the economic importance of tourism (Crouch \& Ritchie, 1999). Currently, tourism has been demonstrated as a prodigious source of value and employment creation (Botti et al., 2008).

Tourism is an extremely important economic activity and susceptible of playing a decisive role in terms of the development of specific regions, where there may on occasion be no other alternatives for attaining such objectives, and correspondingly leveraging the national and historical-cultural potential of the most backward regions (Cabugueira, 2005). An ever-increasing number of destinations worldwide have opened up to, and invested in tourism, turning it into a key driver of socio-economic progress through the creation of jobs and enterprises, export revenues, and infrastructure development (UNWTO, 2015). The tourism sector also represents activities characterised by the enormous possibilities generated in terms of the direct, indirect and induced effects on an economy whether through employment or through the dynamics of other locally located companies. Campos, Mendes and Albino (2006) add that tourism constitutes a sector of activity with a progressively rising level of importance and value to the national and regional economies and fundamentally developed through the provision of services stemming from the needs, expectations, demands and desires of tourist clients in conjunction with the activities ongoing at the respective destination.

According to Jackson and Murphy (2002), the governments themselves identify tourism as a feasible means of attaining economic development given the scarcity of employment in the traditional sectors of activity. The same authors also state that developing tourism inherently involves the production of an integrated territorial destination (scenario, environment), capable of attracting and coping with the level of demand the attraction may bring in the future. This thus means developing all the human and relational capacities which, associated with the capacities endowed by the natural and built resources present, enable the nurturing of a visitor-friendly environment and ensuring they feel comfortable when benefitting from a different scenario to their regular surroundings.

From the perspective of Cabugueira (2005), the majority of activities and services constituting a tourism product are, as a general rule, interlinked with a natural or a cultural attraction. This set of activities enables the proposition of the respective tourism product through productive service activities. In this way, the natural and cultural goods get rendered directly productive and contribute towards the general expansion of the economy.

Rodrigues (2003) refers to how, in other economic activities, it is the product that travels to market, in tourism precisely the opposite takes place. To ensure the effective consumption of the tourism product, the tourist has to travel to the site of the support structure: the tourism destination. The author also affirms that there is no scope for disentangling any approach to the tourism product from the tourist destination itself given that the latter amounts to a central feature to tourism activities. Tourism also generates multiplier effects for economic activities, which reflect not only on important added value but also on capacity through driving the development of other sectors of economic activity (Cabugueira, 2005). According to Botti et al. (2008), geographic proximity plays a relevant role in the perception as to the performance of tourism organisations within the scope of maintaining the sustainability of tourism firms and contributing towards enhancing the competitiveness of the tourism sector.

\subsection{Tourism Competitiveness}

The concept of competitiveness would seem simple at first sight even while its complexity becomes clear when seeking to define and analyse competitiveness according to its various components in the literature (Porter, 1994; Cooke \& Morgan, 
1998; Desrochers \& Suatet, 2004). Porter (1990) argues that its very ambiguity represents a consequence of the enormous variety in the definitions and the different perspectives held on competitiveness rendering any exhaustive or conclusive and consensual definition difficult. In turn, Croes and Kubickova (2013) convey how the main contrasts in the current literature on the imprecision of this concept reflect a multiplicity of meanings and to the extent of challenging any meaningfu application as a concept. Costa, Rita \& Águas (2004) defend how competitiveness constitutes a transversal concern spanning all contemporary societies. In every activity, and not only in business, there is a drive for competitiveness. Being competitive thus becomes a designation and condition for every proposed objective. Crouch and Ritchie (1999) furthermore state that the competitiveness of a particular industry amounts to a crucial determinant to its performance in the world market.

According to Casadesus-Masanell and Ricart (2010), the bulk of the literature on competitiveness concentrates on the geographic unit - region, country or even cluster and has in various ways served to nurture the founding and development of virtuous circles enabling companies to develop strengths that may subsequently be deployed to maintain its international competitiveness. Competitiveness thus becomes understood as the capacity of an organisation, public or private, profit generating or otherwise, to obtain and maintain the comparative advantages that enable it to attain, retain and build on a specific position within the socioeconomic environment (Olmos, 2012).

Meanwhile, Dimoska and Trimcevb (2012) describe how closely interrelated competitiveness is to the notion of competition and generally expressing the capacity of persons, companies, economies or regions to remain in competition locally and internationally and correspondingly mutually benefitting. The same authors attribute competitiveness with the meaning of productivity, perceived as an aggregate value, dynamic in nature and thereby forcing companies to abdicate from inertia and strive for innovation.

To a large extent, competitiveness has contributed towards the construction of social, cultural and economic variables that shape the performance of a country operating in international markets. The creation of wealth remains the motor of economic growth and important leverage of innovation (Dwyer \& Kim, 2003). From the perspective of Dwyer, Mellor, Levaic, Edwards and Kim (2004), the competitiveness of a nation does not encapsulate a result in itself but rather constitutes a means to attain an end within the scope of the final industrial development objective of boosting the wealth of populations. In each and every sector of activity, whether or not profit driven, there is a search for competitiveness. Being competitive represents a catchphrase and a condition for every set objective. Casadesus-Masanell and Ricart (2010) agree that competitiveness proves a concern common to many countries and regions before also affirming how the concept also stands as a means of accelerating development and reaching out to international markets.

According to Alberti and Giusti (2012), tourism is one of the most important sectors on the global scale and correspondingly playing a key role in the development and competitiveness of many regions. In recent years, competitiveness has become one of the most commonly applied concepts for describing the approach to the sustainable development of the travel and tourism industry as well as of tourism destinations themselves. This duly takes into consideration a set of factors referencing the most important facets to this industry, such as the business environment, infrastructures, laws and regulations and the resources available (Bălan, Baluarte \& Veghes, 2009).

The respective competitiveness of tourism destinations remains a complex and relative concept with a proportion of this complexity stemming from the inherent nature of that suggested for the definition of a tourism destination, perceived whether as a place or as a type of real or fictional border, for example, the physical limitations of an island, political boundaries or even those established by a market (Kotler, Bowen \& Markens, 2006). Competitiveness in the tourism sector incorporates the capacity of tourism companies to attract visitors - national and international - who undertake expenditure in the tourism destination that serves to offset the development costs of the activity as well as remunerating the capital invested either equal to or above the opportunity cost prevailing (Dominguez, 2001). Dwyer and Kim (2003) maintain the competitiveness of a tourism destination stems from its ability to provide tourists with goods and services at a better standard than its competitors. Ritchie and Crouch (2010) define tourism competitiveness as the capacity to boost expenditure on tourism, attracting rising visitor numbers, providing them with satisfaction and memorable experiences and all the while doing so in a profitable manner that simultaneously reinforces the wellbeing of both residents and the destination thus preserving its natural capital for future generations. The competitiveness of a tourism system consequently derives from the respective competitiveness of its constituent companies. Tourism firms and companies become competitive whenever able to maintain or improve on their competitive positioning in a market, in competition with other companies and returning appropriate profitability rates. To their managers, our results indicate that even while the tourism market in which the company operates may influence their competitiveness, providing financed public services (infrastructures, the environment and land planning, economic and socio-political stability, training and education, etcetera), under ideal conditions, the competitive success or failure of any tourism company ultimately depends on its own inherent capacities and their ability to absorb market changes (Camisón \& Forés, 2015).

The competitiveness of the tourism sector involves many other factors such as the natural environment (geographic location, landscapes, climate, etcetera...), the built surrounding environment (tourism transport facilities, supply chain infrastructures for leisure and entertainment, services, retail 
stores, hotel chains) and the globalisation of markets (Navickas \& Malakauskaite, 2009). According to Malakauskaite and Navickas (2010), tourism sector competitiveness makes a significant contribution to economic development and stems from the synergies emerging out of the natural and human factors established by the tourism destination resources in turn determined by the capacities of tourism companies to attract new visitors and raise levels of expenditure through the provision of quality goods and services alongside valued experiences.

To grasp the competitiveness of tourism destinations, we should both consider the basic factors to competitive advantage as well as the more advanced aspects to competitive advantage (Omerzel, 2006). The comparative advantages constitute the resources available to a destination with the competitive advantages conveying the capacity a destination displays in efficiently applying these resources over the long term.

Wang and Krakover (2008) add that the long term competitiveness of a tourism destination to a large extent depends on the equilibrium between cooperation and competition among businesses in the tourism industry. Furthermore, the process of branding a tourism destination remains crucial to its long term competitiveness (Boo, Bussel \& Baloglu, 2009). The growing interest in tourism destination competitiveness reflects in the proliferation of the literature on this field (Vila, Darcy \& Elisa, 2015). Many of these research projects set out with the objective of identifying the competitiveness of specific destinations, including the United States of America (Ahmed \& Krohn 1990), Las Vegas (Chon \& Mayer, 1995), European cities (Mazanec, 1995), Southeast Asia (Pearce, 1997), Sun/Lost City in South Africa (Botha, Crompton \& Kim, 1999), Southern Australia (Faulkner, Opperman \& Fredline, 1999), a United States casino resort (D'Hauteserre, 2000), cultural tourism in Toronto (Carmichael, 2002), Mediterranean resorts (Papatheodorou, 2002), Australia (Dwyer et al., 2004), South Korea and Australia (Kim \& Dwyer 2003), Spain and Turkey (Kozak 2003), a ski resort in Canada (Hudson, Ritchie \& Timur, 2004), Asia-Pacific (Enright \& Newton 2005), Slovenia (Omerzel, 2006), the Caribbean (ECLAC, 2009), Brazil (Ritchie \& Crouch, 2010) and Portugal (Estevão \& Ferreira, 2014, Estevão \& Ferreira, 2015)

Other research projects focused on particular facets of destination competitiveness, including its positioning (Pike, 2012; Claveria \& Poluzzi, 2016), management systems (Baker, Hayzelden \& Sussmann, 1996; Arbulú, Lozano \& Rey-Maquiera, 2016), destination commercial profile (Buhalis, 2000; Osman, Johns \& Lugosi, 2014), pricing competitiveness (Dwyer, Forsyth \& Rao, 2002; Seetaram, Forsyth \& Dwyer, 2016), quality management (Assaf \& Tsionas, 2015), the environment (Tang, 2015; Cao et al., 2016), nature based tourism (Tirasattayapitak, Chaiyasain, \& Beeton, 2015; Rahayuningsih, Muntasib, \& Prasetyo, 2016), strategic management (Phillips \& Moutinho, 2014; Evans, 2016), and organised circuits/routes (Rodríguez, Molina, Pérez, \& Caballero, 2012; Manhas, Kour, \& Bhagata, 2014).

Furthermore, there is also the group of studies concentrating on measuring the competitiveness of tourism destinations
(Cracolici \& Nijkamp, 2009; Cores, 2011; Croes \& Kubickova, 2013) research based on the development of models and general theories as to destination competitiveness (Porter, 1990; Crouch \& Ritchie, 1999; Dwyer \& Kim, 2003; Malakauskaite \& Navickas, 2010; Estevão \& Ferreira, 2014, Estevão \& Ferreira, 2015).

\subsection{The Porter Diamond}

Porter (1990) proposed that the success of any specific company or sector interrelates with the national conditions prevailing in the country of origin given how these drive and enable the adoption of appropriate strategies based upon contexts beneficial to progress. The success of the company and the sectors, based upon these favourable factors, in turn, constitute the competitive advantage of a country. Porter (1990) points out how it is companies and not countries that compete in the international market even while the success of those companies may be attributable to the prevailing economic environment, government institutions and policies. This correspondingly means that the competitiveness of a nation or a region gets built on the success companies attain in international markets. According to Porter (1990), analysis should incorporate specific industries or segments of industry and focus not on the economy as a whole as it is unthinkable for competitive advantage to exist in every sector. His model adopts four determinants as decisive factors in the competitive advantage of a nation, region or cluster. These determinants are: (i) the factor conditions: the endowment of a country with factors of production such as the specialist labour skills or infrastructures necessary to the ongoing competitive activities of a specific industry; (ii) the strategic structure and business rivalries: conditions that nationally regulate the founding, organisation and management of firms and companies and the nature of their internal rivalries; (iii) The demand conditions: the characteristics of the internal demand for a specific good or service, especially the presence of sophisticated and demanding clients; (iv) the existence of related and support industries: the existence or otherwise of supply sectors and/or related chains that attain international market competitive standards. This determinant incorporates issues related to economies of scale and agglomeration and their effect on competitiveness.

To these attributes, Porter (1990) added the action of government and the role of chance (events beyond the scope of control of companies) and he thus defined the Competitive Diamond. There have been a series of studies adopting this model for their research projects (Moon, Rugman, \& Verbeke, 1998; Mann \& Byun, 2011; Ozer, Latif, Sarusik, \& Ergun, 2012; Estevão and Ferreira, 2014), spanning various sectors of activity and especially tourism.

\section{Methodology}

\subsection{Geographic area of study and unit of analysis}

Portugal is an excellent tourism destination both for arrivals from other parts of the globe and for national residents 
themselves. The favourable climate, a welcoming population and the ease in communication and transport, the potential diversity in the tourism range, the extent and variety in the coastal regions and river systems represent some of the factors contributing towards the success and evolution of this sector. Portugal also holds in its advantage a particularly wide physiographic diversity, with landscapes, gastronomy, heritage, ambiences and cultures able to respond to different motivations. Political stability and integration into the European Union and the Euro, associated with an image as a safe destination have also aided in deepening the attractiveness of Portugal (Albuquerque \& Agostinho, 2001). According to the Strategic Plan for Tourism - Horizon 2013-2015, Portugal should join those European destinations with growth most closely aligned with principles of sustainable development, leveraging a value proposals backed up by the distinctive and innovative characteristics of the country.

The present study focused on the regional tourism areas defined in Law no. 33/2013 of 16 May, which established a new juridical regime for the regional tourism areas of mainland Portugal, which include those covered by each one of the respective five units constituting NUTS level II - the Nomenclature for Territorial Units for Statistical Purposes on mainland Portugal and the two Regional Directorates of Tourism - Madeira and the Azores.

In each of the regional tourism areas, a regional tourism entity was set up to operate as the managing entity structured as a collective person of territorial scope in public law, endowed with administrative and financial autonomy and its own asset base. Law no. 33/2013 of 16 May served to regulate the reorganisation of diverse regional tourism entities, which were abolished through merger into the regional tourism entities, tourism development poles, succeeding those with such hitherto attributions in accordance with the following: the Regional Tourism Entity of Porto and Norte taking over the attributions formerly held by the Douro development pole; the Regional Tourism Entity of Centro following on from the Serra da Estrela, Leiria-Fátima and Oeste tourism development poles and the Regional Tourism Entity of the Alentejo assuming the mantle hitherto attributed to the poles of Alqueva and Alentejo Litoral.

These regional tourism entities hold competences for tourism development in their respective regions, seeking the sustained leveraging of its tourism resources and within the framework of the tourism policy guidelines and directives defined by the government and the multi-year plans of central and local administrations.

The geographic area of study thus encapsulates the Regional Tourism Areas of Portugal as defined in Law no. 33/2013 of 16 May. The research unit of analysis thus derives from companies with activities characteristic of the WTO (2001) satellite account to a total five decimal points.

\subsection{Data, Methods and Variables}

The methodology adopted by this research for the data collection phase required recourse to primary data, such as that returned by the questionnaire research tool and delivered to senior managers at the 4,560 companies. We have obtained a final sample with 446 responses.

The instrument applied was structured according to Porter's Diamond Model (1990) resulting in a questionnaire containing 55 items measured on a 5-point Likert scale on which one represents the lowest level of importance or agreement and five the maximum level of importance or agreement. These items evaluate aspects related with the determinants of the Diamond, especially: the conditions of the factors and the demand, the strategy, structure and business rivalries, the existence of related and support industries and the government. The questionnaire was provided by the Monitor Group of Council on Competitiveness and used in the investigation of Porter (2001).

\subsection{Sample Characteristics}

Of the 446 companies surveyed, the majority belong to either the Centro (23.1\%) or the Lisbon (22.9\%) Regional Tourism Districts. The hotel sector predominates in the study sample (65.2\%). In particular, Hotels and Restaurants were the most common CAE typology among respondents with some 132 companies (29.6\%), followed by Accommodation with Restaurants and Traditional Type Restaurants on $6.7 \%$ and Rural Tourism on $6 \%$. The number of respondent company employees varied from 1 to 527 with an average of 21 and a median of 10 members of staff with almost a majority employing at least 10 staff (47.9\%) and therefore micro-companies, or between 10 and 50 members of staff (44.9\%). In relation to their legal structures, almost three-quarters of the sample (73.6\%) are private limited companies. As regards their year of foundation, $42.6 \%$ began after 1999. Over $60 \%$ of questionnaire respondents worked primarily in management posts with a majority holding higher education qualifications (55.9\%) following by professional training and secondary school qualifications with $20.30 \%$ and $19.90 \%$ respectively. The main respondent age groups were the following: between 30 and 39 (29.20\%), 40 and 49 (28.5\%) and between 50 and 64 years of age (25.70\%), with only 58 respondents found in the 20 to 29 age range.

\section{Analysis and Discussion of the Results}

A first phase carried out Factorial Analysis on the 55 items under study. The analysis of internal consistency indices obtained led to the exclusion of two items and thus significantly improving scale reliability. The 53 items were then again subject to Factorial Analysis techniques to obtain a result of 0.807 for the $\mathrm{KMO}$ and a value of $\mathrm{p}<0.001$ in accordance with the Bartlett Test and demonstrating the appropriateness of the analysis model applied to the study sample. To extract the axes, we made recourse to Principal Component Analysis before then determining the number of axes to retain through Cattell's Scree Plot. The five axes retained explain $46.5 \%$ of total variance. Following Varimax rotation, we obtained the distribution of the items in accordance with the factors and as presented in Table 1. In order to facilitate interpretation, we removed all factorial loads below 0.3 . 
Table 1 - Factorial Matrix obtained by Varimax Rotation

i1. There is good quality accommodation

i2. There is a variety of accommodation

i3. There is a good accommodation quality/price relationship

i4. The destination has appropriate transport access standards

i5. Local tourism transport is efficient

i6. Local tourism transport is good quality

i7. Restaurant services meet the demands of local tourism flows

i8. There are sufficient leisure services to meet tourism demand

i9. In general terms, there are enough support companies to meet the level of tourism demand (for example, bars, restaurants, hotels, travel agencies, etc.)

i10. Tourism companies run cultural programs that ensure visitor satisfaction

i11. The general quality of transport access and infrastructures is good

i12. Tourism companies generally act in accordance with the principles of business ethics

i13. The quality of human resource training in the sector is good

i14. There are enough specialised professionals in the sector

i15. The general quality of life easily retains employees

i16. In general terms, tourism company managers are competent

i17. The labour legislation regulating the sector of activity proves motivating to employees

i18. It is easy to obtain financing for the sector

i19. The necessary investment costs to launch activities are accessible

i20. The 'Cleaning'/Sanitation standards are good

i21. The natural resources are duly preserved

i22. The historical and cultural resources are well conserved

i23. Companies openly share information

i24. There is cooperation between public and private tourism sector companies

i25. The location of the company (region) contributes towards innovating its business

i26. Relationships between competitors are characterised by cooperation

i27. The region is safe for tourists

i28. The tourists are demanding

i29. The educational level of the tourists influences their choice of tourism destination

i30. Tourists generally recognise this as a quality destination

i31. There is a concern over ascertaining whether tourists return

i32. It is important to learn the opinions of clients about the tourism destination

i33. The company contributes to regional development

i34. The local competition is intense for the company

i35. There is a variety of companies in this sector of activity

i36. Innovation is important to company success

i37. Differentiation in the products and services sold is important

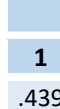

Component

439

.313

2

.501

.582

.513

.734

.726

.681

355

.526

.528

.658

.619

.564

\begin{tabular}{|l|l|}
.367 & .396 \\
\hline
\end{tabular}

\begin{tabular}{|l|l|}
.363 & .592 \\
\hline
\end{tabular}

\begin{tabular}{|l|l|}
.365 & .578
\end{tabular}

Note: Extraction Method: Principal Component Analysis. Rotation Method: Varimax with Kaiser Normalization. a. Rotation converged in 7 iterations. Source: Authors. 
The factorial structure obtained displays how Factor 1 gathered the items relative to "Supply and Demand Conditions", Factor 2 interrelates with "Government Policies", Factor 3 concentrates information on "Related and Support Industries", whilst Factor 4 focuses on "Factor/Resource Conditions and Cooperation" with Factor 5 approaching "R\&D Networks".
In order to measure internal consistency, we applied Cronbach's Alpha (Table 2), reporting satisfactory levels ranging between 0.787 (Supply and Demand Conditions) and 0.912 (Complete Scale).

Table 2 - Cronbach's Alpha for the Totality of the Items under Analysis and the Respective Subscales

\begin{tabular}{|l|c|c|}
\hline \multicolumn{1}{|c|}{ Scale } & No. (items) & Cronbach's Alpha \\
\hline COMPLETE SCALE & 53 & 0.912 \\
\hline Related and Support Industries & 11 & 0.854 \\
\hline Factor/Resource Conditions and Cooperation & 15 & 0.842 \\
\hline Supply and Demand Conditions & 11 & 0.787 \\
\hline Government Policies & 8 & 0.899 \\
\hline R\&D Networks & 8 & 0.826 \\
\hline
\end{tabular}

Source: Authors.

In order to assess the results obtained, we proceeded with the calculation of the rankings received by each of the dimensions. To ensure result compatibility, the ranks were weighted by the number of items contained by each dimension and to this end assuming one as the minimum value and five as the maximum.
The missing data were replaced by the average attributed to the corresponding dimension, which corresponds to approximately $5 \%$ of the total data. Table 3 reports on the basic descriptive statistics reported for each of the dimensions.

Table 3 - Basic Descriptive Statistics for the Weighted Rankings

\begin{tabular}{|l|l|l|l|l|l|}
\hline \multicolumn{1}{|c|}{ Factors } & No. & Min. & Max. & Average & Stand. Devia. \\
\hline Related and Support Industries & 446 & 1.42 & 5.00 & 3.50 & 0.69 \\
\hline Factor/Resource Conditions and Cooperation & 446 & 1.33 & 4.50 & 3.18 & 0.58 \\
\hline Supply and Demand Conditions & 446 & 1.91 & 5.00 & 4.14 & 0.47 \\
\hline Government Policies & 446 & 1.00 & 5.00 & 2.87 & 0.78 \\
\hline R\&D Networks & 446 & 1.38 & 5.00 & 4.12 & 0.59 \\
\hline
\end{tabular}

Source: Authors.

We would note that the "Supply and Demand Conditions" and "R\&D Networks" dimensions receive the highest values from respondents whilst "Government Policies" constitutes the dimension returning the lowest average result. The "Supply and Demand Conditions" dimension, in turn, generates the greatest consensus among respondents. Furthermore, the "Government
Policies" dimension records the most homogeneous responses. Analysis of the average weightings returned by the different dimensions approached in accordance with the location of the company in its regional tourism area (Fig.1) results in the following:

\section{Figure 1 - Average weightings returned by analysis of the Regional Area/Directorate of Tourism}

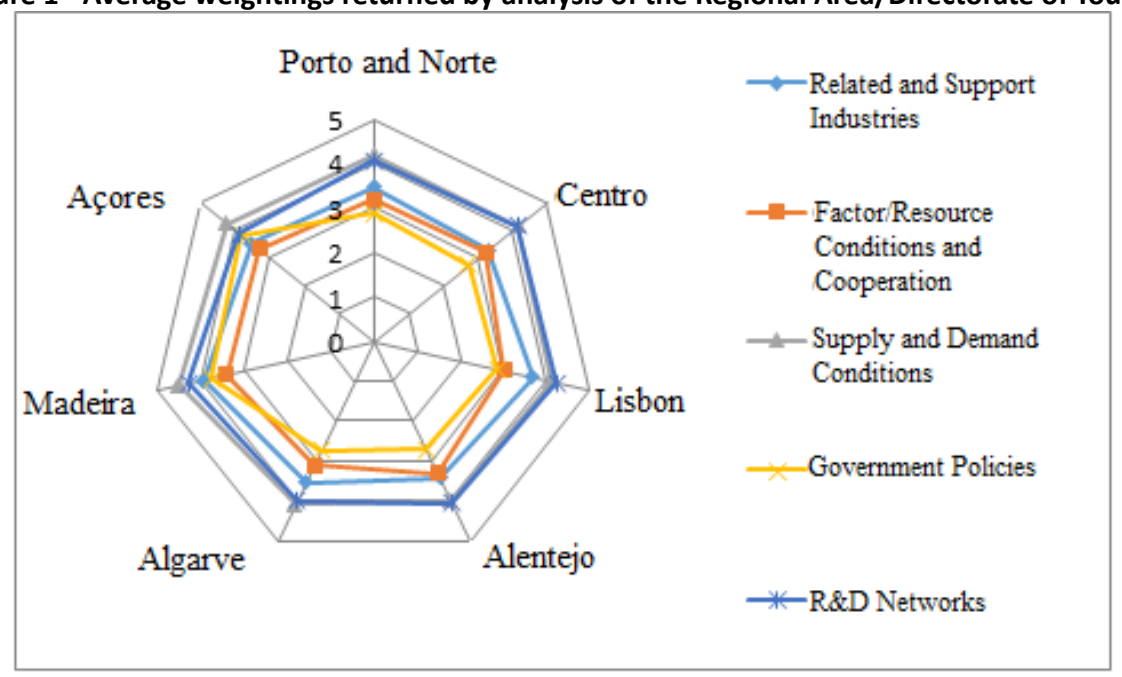

Source: Authors. 
- In the case of Related and Support Industries, they register their highest average weighting in Madeira and their lowest in Centro;

- As regards the case of Factor Conditions/Resources and Cooperation, the highest average weighting occurs in Madeira and the lowest in Lisbon;

- Regarding Supply and Demand Conditions, their average weighting peaks in Madeira with the Alentejo accounting for the lowest level;

- In terms of Government Policies, these receive their highest average weightings in the Azores followed by Madeira and their lowest in the Alentejo;
- Finally, the R\&D Networks item records its highest average ranking in Madeira followed by Lisbon whilst returning its lowest level in the Azores.

The dimensions obtained from the model put forward in Figure 2 follow recourse to the PLS (Partial Least Squares) approach through the application of Smart PLS 3.0 software (Ringle, Wende, \& Becker, 2015). The criteria applied in the construction of the final model presented here stem from establishing and eliminating the relationships between variables so as to return a higher level of reliability and model measurement validity through, in accordance with the theoretical foundations, eliminating all the items with coefficients of below 0.3 .

Figure 2 - Conceptual Model of the Existing Relationships

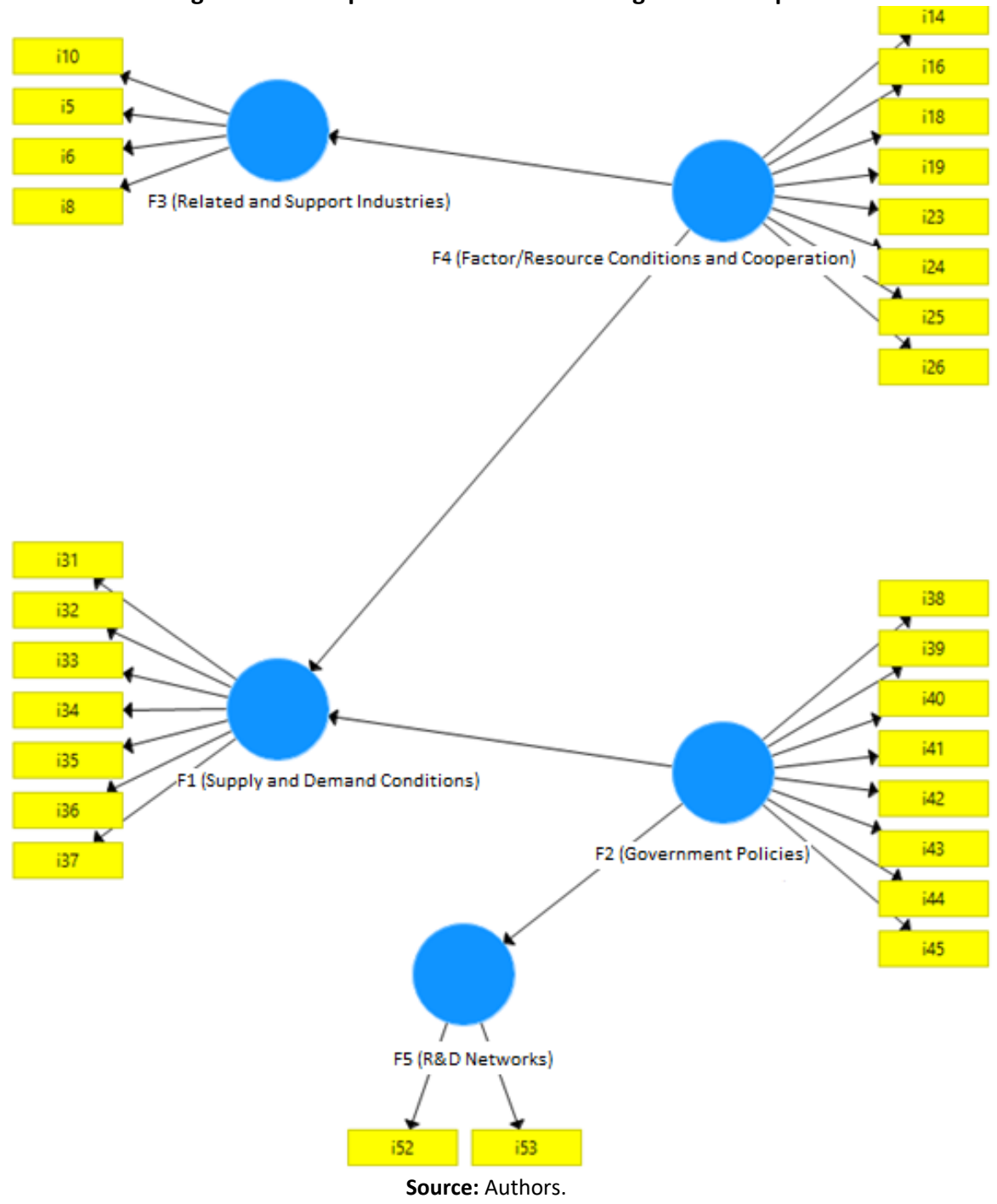

In addition to carrying out model estimations for the data set as a whole, we also calculated the models for each of the respective tourism regions. Figures 3 to 10 display the estimated models for the entire data set and each of the tourism regions under analysis. 
Figure 3 - Estimated Model - Complete Data Set

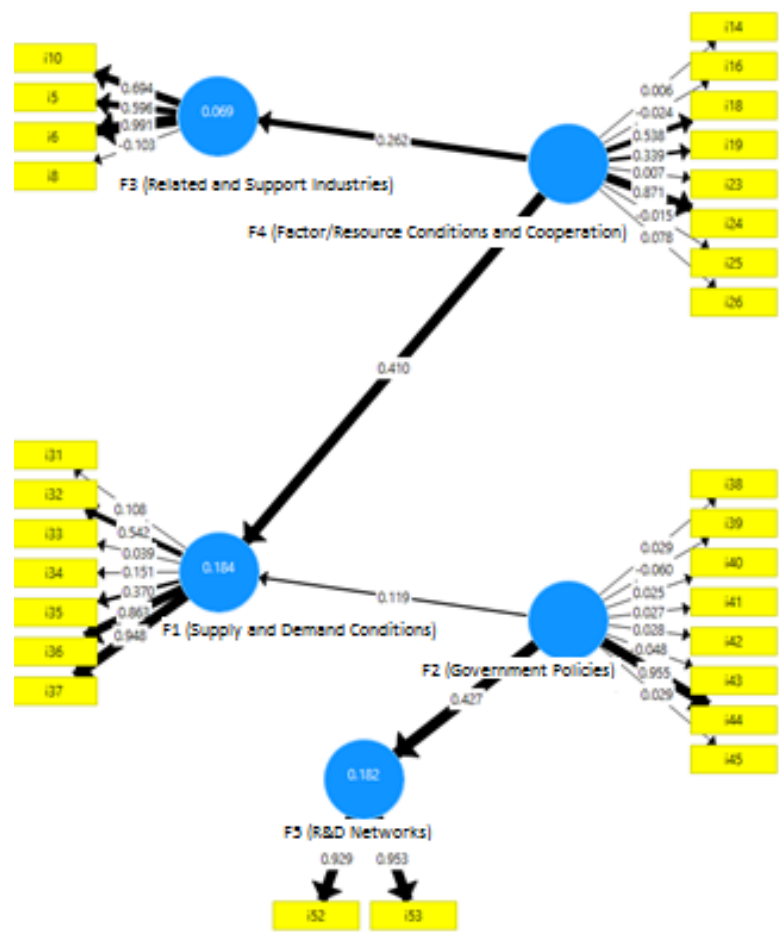

Figure 4 - Estimated Model - Regional Tourism Area of Porto and Norte

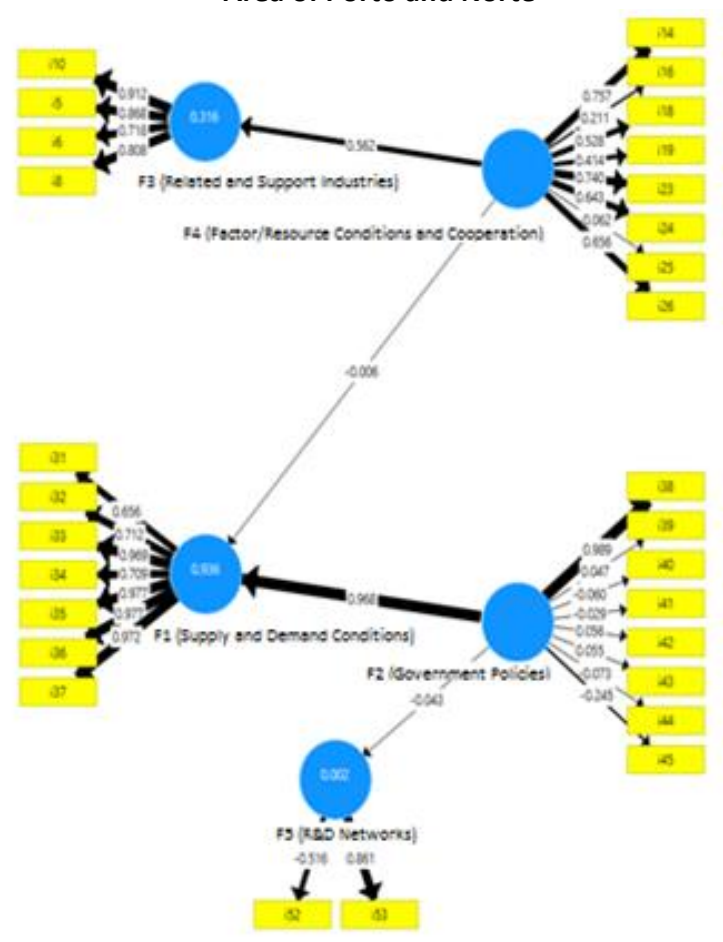

Figure 5 - Estimated Model - Regional Tourism Area of Centro

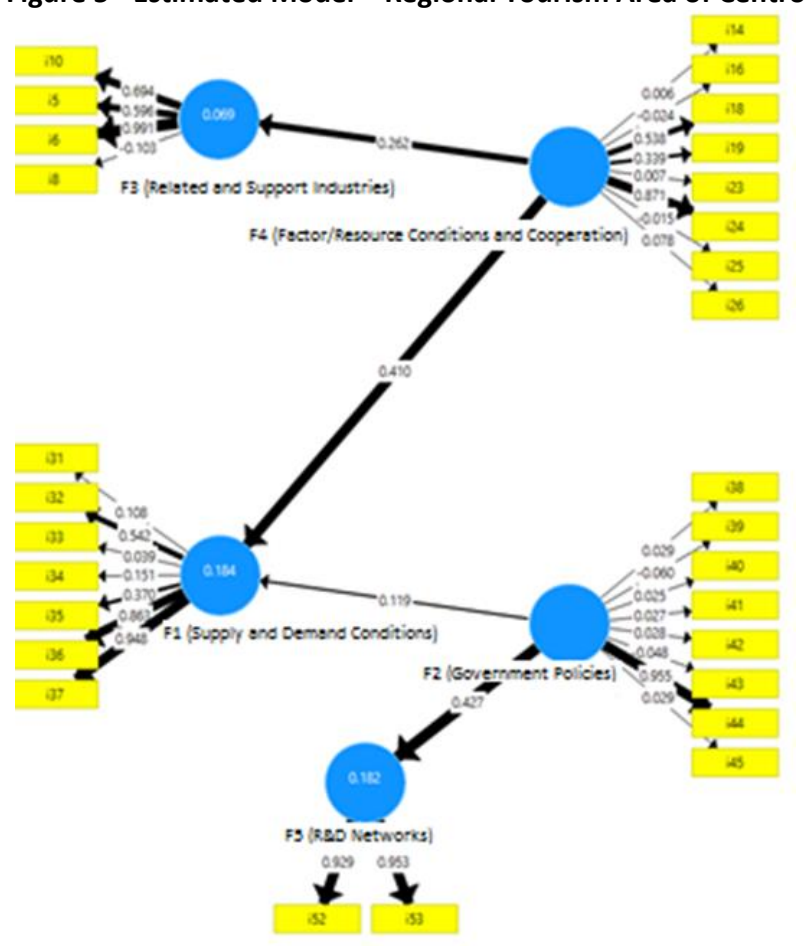

Figure 6 - Estimated Model - Regional Tourism Area of Lisbon

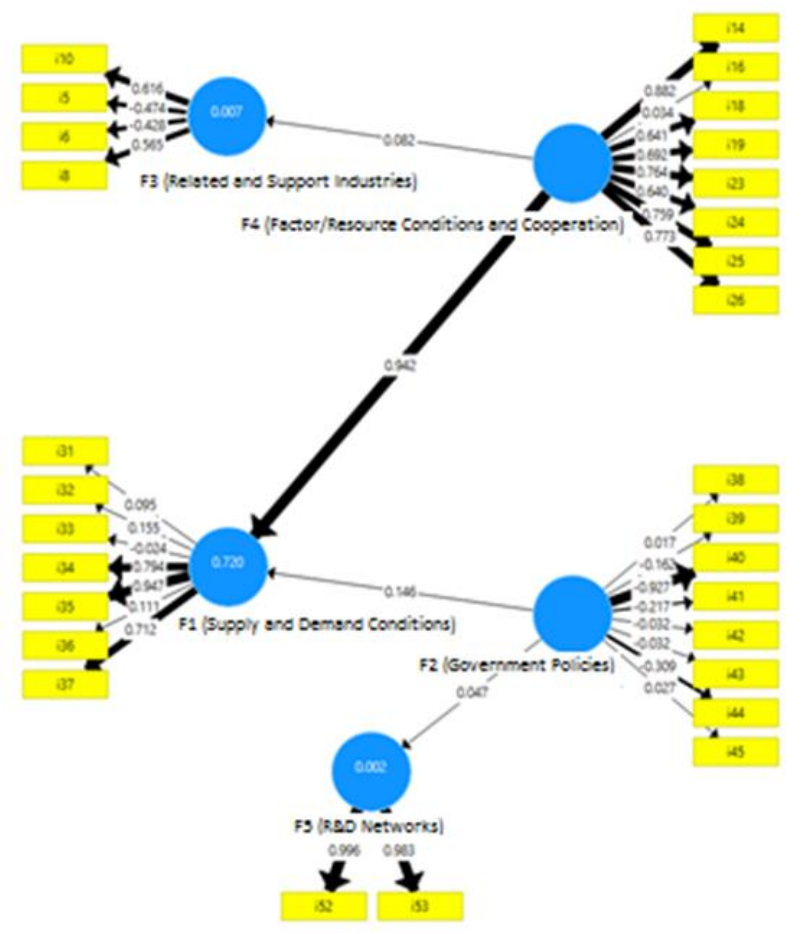


Figure 7 - Estimated Model - Regional Tourism Area of the Alentejo

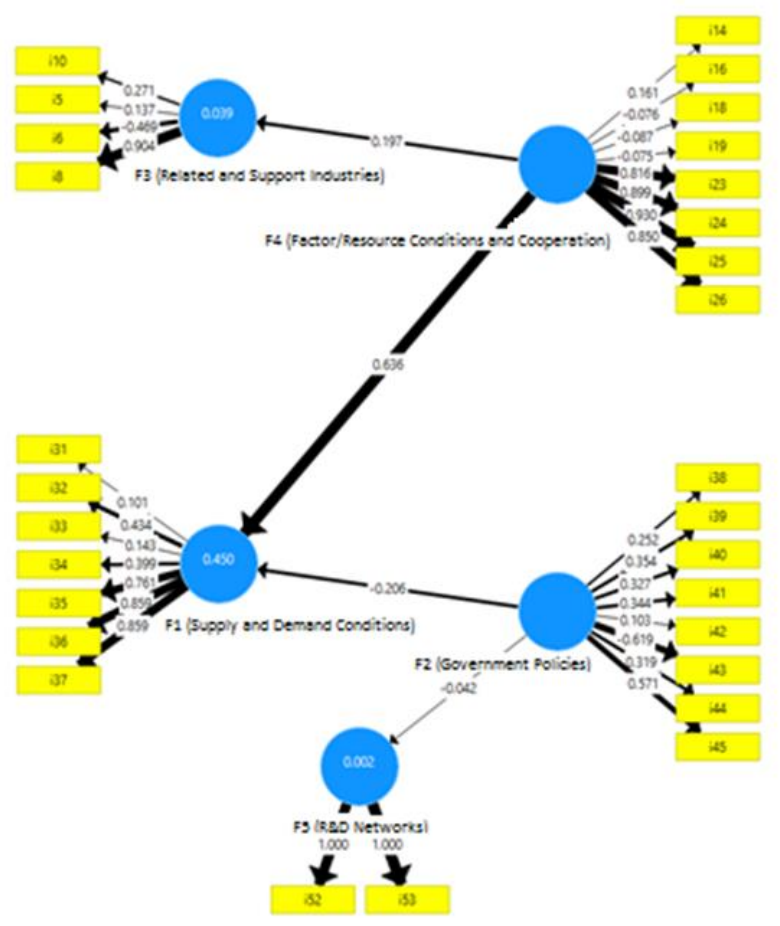

Figure 8 - Estimated Model - Regional Tourism Area of the Algarve

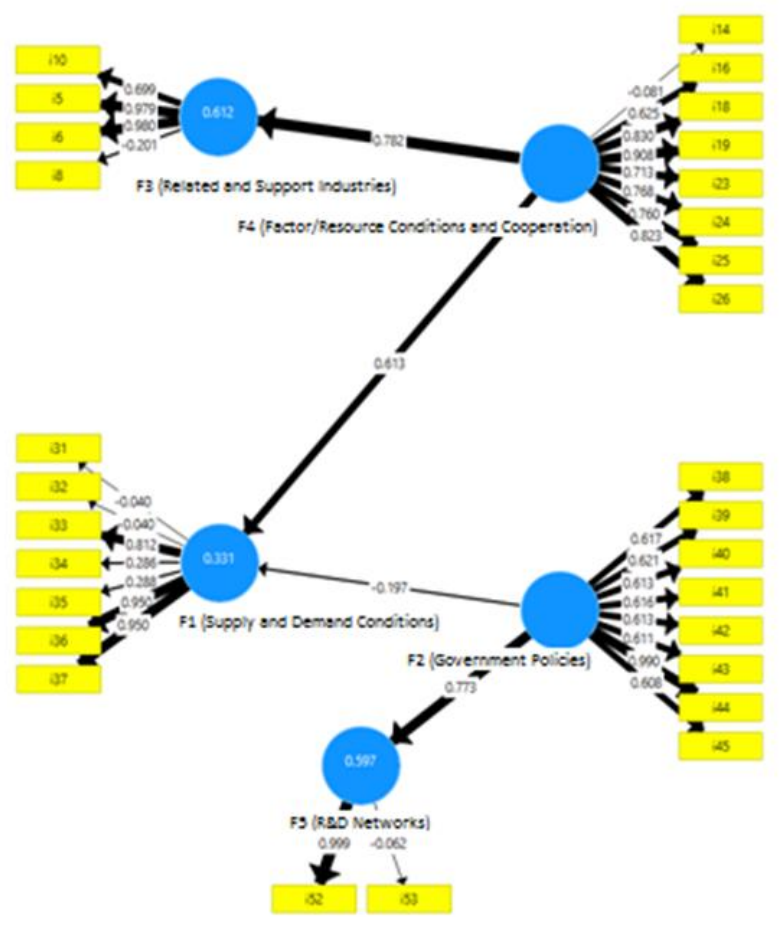

Table 4 displays the results stemming from the Estimated Coefficients (Path Coefficients and Outer Loadings), Determinant Coefficients $\left(R^{2}\right)$, Composite Reliability $(\rho c)$ and
Figure 9 - Estimated Model - Regional Directorate of Tourism of Madeira

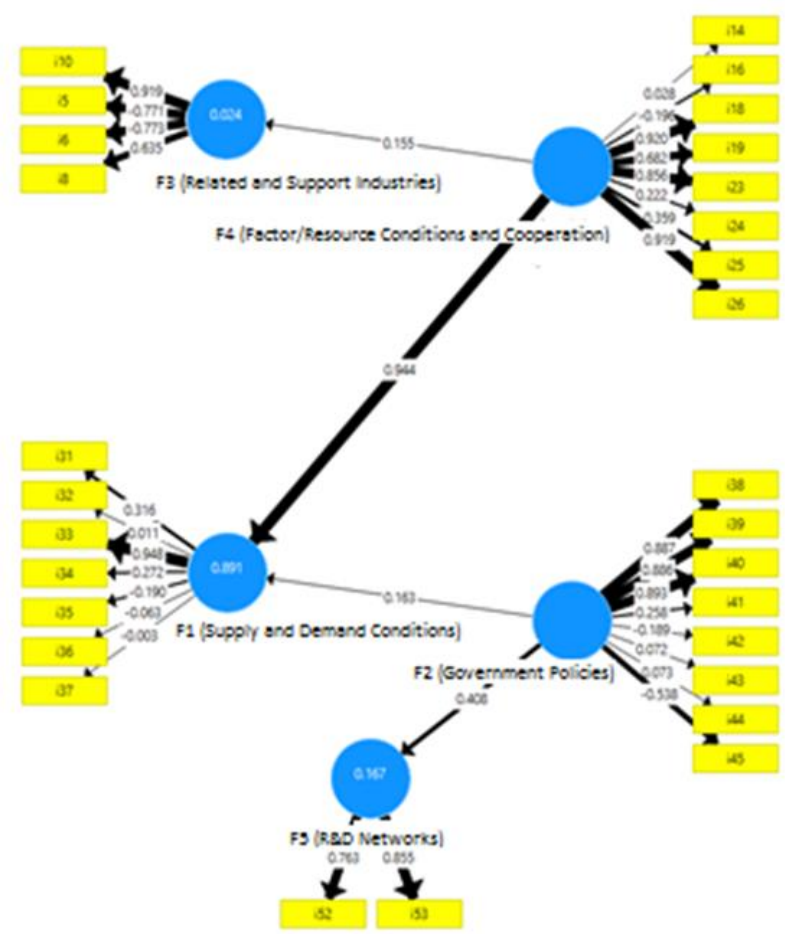

Figure 10 - Estimated Model - Regional Directorate of Tourism of the Azores

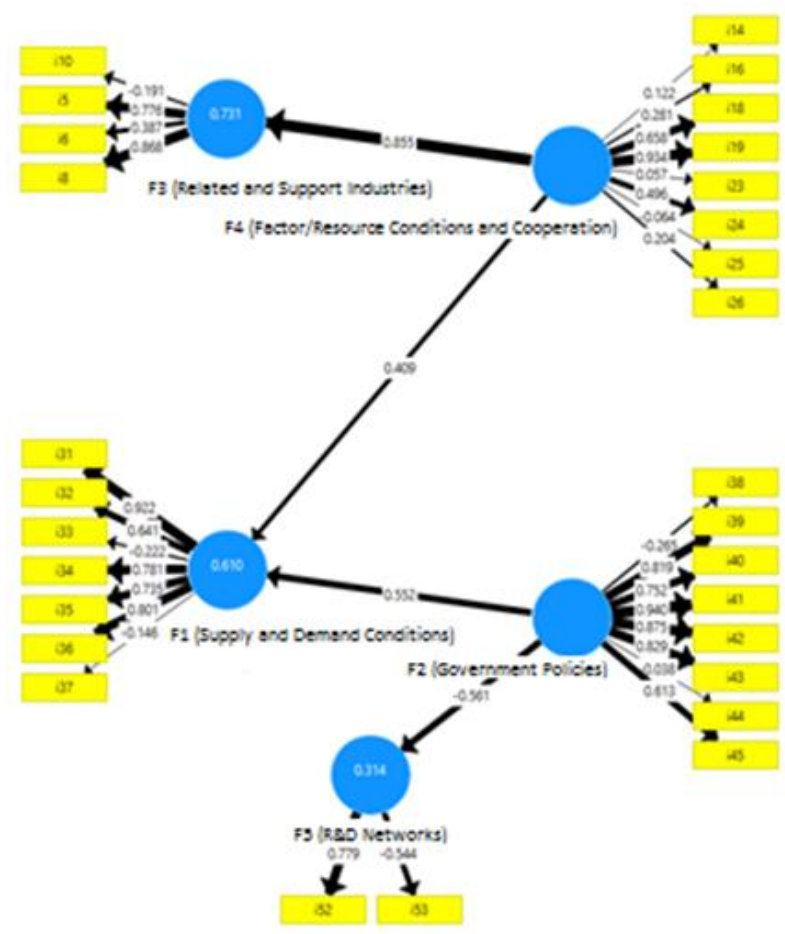

Average Variance Extracted (AVE) for the analytical models estimated for the complete data set and for each tourism region. 
Table 4 - Estimated Coefficients (Path Coefficients), Determinant Coefficients $\left(R^{2}\right)$, Composite Reliability ( $\left.\rho c\right)$ and Average Variance Extracted (AVE) for the Estimated Models for the CompleteSample (global) and for the Different Sectors of Activity

\begin{tabular}{|c|c|c|c|c|c|c|c|c|}
\hline & $\begin{array}{l}\bar{\pi} \\
\text { 은 }\end{array}$ & 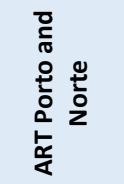 & 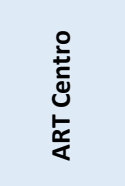 & 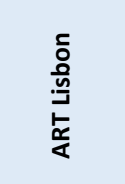 & 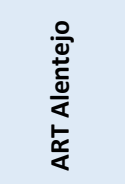 & $\begin{array}{l}\frac{1}{2} \\
\frac{1}{0} \\
\frac{0}{4} \\
\frac{1}{6} \\
\frac{\alpha}{4}\end{array}$ & 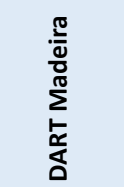 & 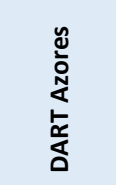 \\
\hline Number of observations & 446 & 80 & 103 & 102 & 78 & 51 & 19 & 13 \\
\hline \multicolumn{9}{|l|}{ Path Coefficients } \\
\hline $\begin{array}{l}\text { F2 (Government Policies) } \rightarrow \text { F1 } \\
\text { (Supply and Demand Conditions) }\end{array}$ & 0.157 & $0.968 * * *$ & 0.119 & 0.146 & -0.206 & -0.197 & 0.163 & $0.552 *$ \\
\hline $\begin{array}{l}\text { F2 (Government Policies) } \rightarrow \text { F5 (R\&D } \\
\text { Networks) }\end{array}$ & 0.141 & -0.043 & 0.427 & 0.047 & -0.042 & $0.773 *$ & 0.408 & -0.561 \\
\hline $\begin{array}{l}\text { F4 (Factor Conditions/Resources and } \\
\text { Cooperation) } \rightarrow \text { F1 (Supply and } \\
\text { Demand Conditions) }\end{array}$ & $0.344 * *$ & -0.006 & 0.410 & $0.942 * * *$ & $0.636^{* *}$ & 0.613 & $0.944 * *$ & 0.409 \\
\hline $\begin{array}{l}\text { F4 (Factor Conditions/Resources and } \\
\text { Cooperation) } \rightarrow \text { F3 (Related and } \\
\text { Support Industries) }\end{array}$ & $0.185^{*}$ & $0.562 * *$ & 0.262 & 0.082 & 0.197 & $0.782 *$ & 0.155 & 0.885 \\
\hline \multicolumn{9}{|l|}{$\mathbf{R}^{2}$} \\
\hline F1 (Supply and Demand Conditions) & 0.168 & $0.936 * * *$ & 0.184 & $0.720 * * *$ & $0.450 * *$ & $0.331 * * *$ & $0.891 * * *$ & $0.610 * * *$ \\
\hline F3 (Related and Support Industries) & 0.034 & 0.316 & 0.069 & 0.007 & 0.039 & 0.612 & 0.024 & $0.731^{* * *}$ \\
\hline F5 (R\&D Networks) & 0.020 & 0.002 & 0.182 & 0.002 & 0.002 & 0.597 & 0.167 & $0.314^{*}$ \\
\hline \multicolumn{9}{|l|}{$\rho c$} \\
\hline F1 (Supply and Demand Conditions) & $0.778 * * *$ & 0.953 & $0.651 * * *$ & $0.613^{* * *}$ & $0.735 * * *$ & $0.702 * * *$ & 0.221 & 0.761 \\
\hline F2 (Government Policies) & $0.608^{* *}$ & 0.073 & 0.121 & 0.277 & 0.287 & $0.865^{* * *}$ & $0.512^{*}$ & $0.837 * * *$ \\
\hline F3 (Related and Support Industries) & $0.803^{* * *}$ & 0.898 & $0.686 * * *$ & 0.026 & 0.199 & $0.796 * * *$ & 0.000 & $0.579 * * *$ \\
\hline $\begin{array}{l}\text { F4 (Factor Conditions/Resources and } \\
\text { Cooperation) }\end{array}$ & $0.820 * * *$ & 0.732 & 0.322 & $0.866 * * *$ & $0.705^{* * *}$ & $0.884 * * *$ & $0.659 * * *$ & 0.534 \\
\hline F5 (R\&D Networks) & $0.697 * * *$ & 0.107 & $0.939 * * *$ & $0.989 * * *$ & $1.000 * * *$ & $0.468^{* *}$ & $0.792 * * *$ & $0.048^{* * *}$ \\
\hline \multicolumn{9}{|l|}{ AVE } \\
\hline F1 (Supply and Demand Conditions) & $0.363^{* * *}$ & $0.747 * * *$ & $0.301 * * *$ & $0.297 * * *$ & $0.348 * * *$ & $0.376 * * *$ & $0.159 * * *$ & 0.446 \\
\hline F2 (Government Policies) & $0.228^{* * *}$ & $0.132 * * *$ & 0.115 & 0.129 & 0.154 & 0.452 & $0.347 * * *$ & $0.503^{* * *}$ \\
\hline F3 (Related and Support Industries) & $0.506 * * *$ & $0.688 * * *$ & $0.457 * * *$ & $0.277 * * *$ & $0.283^{* * *}$ & $0.612 * * *$ & $0.610 * * *$ & $0.385^{* * *}$ \\
\hline $\begin{array}{l}\text { F4 (Factor Conditions/Resources and } \\
\text { Cooperation) }\end{array}$ & $0.377 * * *$ & $0.308 * * *$ & 0.146 & $0.480 * * *$ & $0.388 * * *$ & $0.533 * * *$ & $0.388 * * *$ & 0.212 \\
\hline F5 (R\&D Networks) & $0.575^{* * *}$ & $0.504^{* * *}$ & $0.886 * * *$ & $0.979 * * *$ & $1.000 * * *$ & $0.501 * * *$ & $0.657 * * *$ & $0.452 * * *$ \\
\hline
\end{tabular}

***Significant at .01; **Significant at .05; ${ }^{*}$ Significant at .10 .

Henseler, Ringle, \& Sinkovics, (2009) and Hair, Sarstedt, Ringle, \& Mena, (2012) recommend composite reliability $(\rho c)$ results of greater than 0.7 with AVE results in excess of 0.5 . Considering the complete set of data, the adjusted model displays $\rho$ c results almost always above 0.7 while the AVE results prove below the level of 0.5 for the majority of the items. The constructs under analysis return moderate values for $\mathrm{R}^{2}$ (ranging from 0.002 to 0.936 , indicating the proportion of the variability of the latent variable which is explained by the analysis items).

Analysis of the standardised coefficients enables analysis of the relationships underlying the constructs. In order to test whether the estimated coefficients differ significantly from zero, we applied the $t$-value and their respective $p$-value calculations through recourse to bootstrap. For the complete set of data, the analysis demonstrates that only the relationships "F4 (Factor Conditions/Resources and Cooperation) $\rightarrow$ F1 (Supply and Demand Conditions)" and "F4 (Factor Conditions/Resources and Cooperation) $\rightarrow$ F3 (Related and Support Industries)" hold statistical significance.

Undertaking more detailed analysis of each model adjusted to each Regional Area/Directorate of Tourism, we report that the relationships between the factors under study take on different levels of importance relative to each different tourism area/directorate. In Figure 11, we detail the most important items in each factor for each respective tourism area/directorate: 
Figure 11 - Factor/Item Relationship by Regional Area/Directorate of Tourism

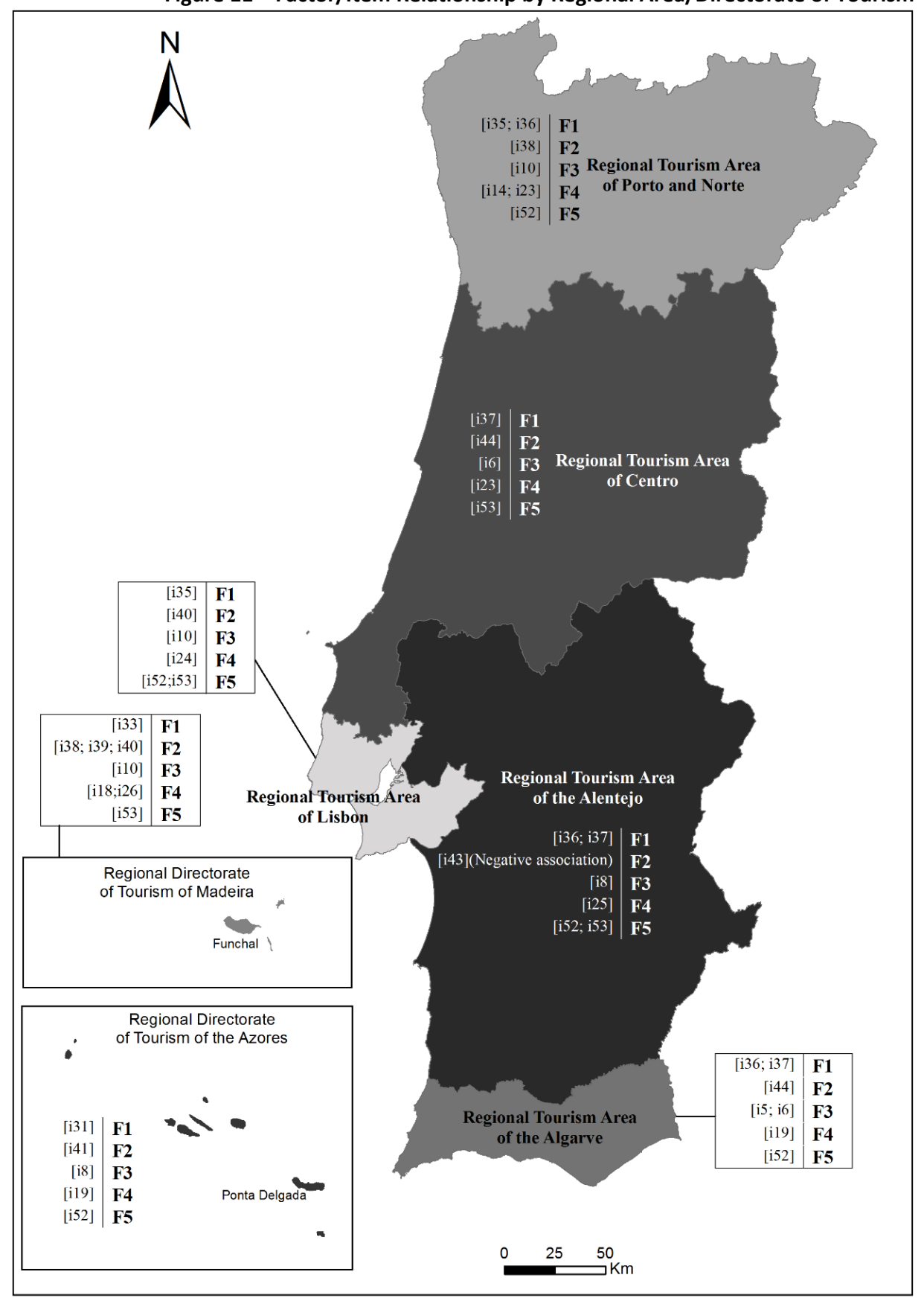

We may thus report how item 35 - "There is a variety of companies in your sector of activity" takes on great importance in the Regional Tourism Areas of Porto and Norte and Lisbon and undoubtedly in large part due to their hosting the largest cities in the country and hence with clearly more diverse ranges of supply.

In relation to item 36 - "Innovation is important to company success", this stands to the fore in the Regional Areas of Porto and Norte, the Alentejo and the Algarve representing a solution in demand among companies in these regions within the scope of their meeting new sources and types of demand.

Item 38 - "The government promotes regional development" plays a relevant role in the Regional Tourism Area of Porto and
Norte and in the Directorate of Tourism of Madeira whilst item 37 - "Differentiation in terms of the products and services sold is important" stands out in the Tourism Areas of Centro, the Alentejo and the Algarve, which derives from the diversity of tourism products provided to tourists in recent years in order to counter seasonality and capitalise on the varied tourism resources in existence and that were broadly unknown to both national and international tourists until relatively quite recently.

The regional areas of Porto and Norte, Lisbon and Madeira emphasise item 10 - "Tourism companies run cultural programs to provide visitor satisfaction", reflected in the cultural agendas ongoing in the cities of Porto, Lisbon and Funchal. 
There is clear importance attributed by the Regional Tourism Areas of Porto and Norte and of Lisbon to item 14 - "There are enough specialised professionals in the sector of activity" primarily due to good professionals preferring to be in environments that endow them with professional visibility. Despite only respondents from the Areas of Porto and Norte and Centro considering "Companies openly share information" - item 23, this conveys how managers and owners remain closed in upon themselves and do not yet perceive such sharing as a means of obtaining joint objectives.

In relation to the R\&D Networks factor, there is a broad consensus surrounding "Raising funds for research" - item 52, with only the Regional Directorate of Madeira not valuing this item. This proves the relevance awarded to the studies made by national universities and polytechnics as a means of boosting regional development.

Centro and the Algarve are unanimous in recognising how "The state has undertaken security measures against terrorism and/or criminality" - item 44 and with this latter regional area hosting the most tourists and from everywhere in the world, with correspondingly different ethnic, racial and religious backgrounds and hence the concern over security and the protecting of this image as a safe tourism destination.

Item 53 - "Attracting new investors" constitutes one of the concerns of the areas of Centro, Lisbon, the Alentejo and Madeira stemming from how such proves necessary to advancing with the major projects already planned and that would drive the potential of the respective tourism destinations.

We would highlight the fact that only companies in the Regional Directorate of Tourism of Madeira attribute recognition to the value of item 33 - "Your company contributes towards regional development" - and item 26 - "Your relationship with the competition is characterised by cooperation", as this region mostly "lives off" the tourism sector and, whether despite or because of its displacement from the mainland, grasps the importance of cooperation with the competition as a means of becoming stronger.

\section{Conclusions}

This research allowed to identify the existence of various factors that are determinant to the competitiveness of the regional areas/directorates of tourism of Portugal - F1 - "Supply and Demand Conditions", F2 - "Government Policies", F3 "Related and Support Industries", F4 - "Factor Conditions /Resources and Cooperation" and F5 - "R\&D Networks" with distinct weightings. These factors in turn highlight items interrelated with concerns over the variety in existing tourism companies, the competition and innovation as a factor of success. We furthermore verified that only two areas attributed recognition to the role played by the government in the promotion of regional development and encapsulating the lack of belief managers and entrepreneurs hold in central and local government on the one hand whilst differentiation was deemed to play a leading role in the competitiveness of a particular tourism destination (Estevão \& Ferreira, 2015). We would also state that having comparative advantages does not prove sufficient to any destination that instead requires competitive advantages (Crouch \& Ritchie, 1999) and this duly reflects in the value placed on cultural programs designed to ensure visitor satisfaction. We also report that in general terms these companies do not either share information or openly cooperate as these ae not perceived as the best paths towards obtaining objectives, which in tourism tend to be very similar. We also ascertained how higher education has begun to gain recognition as a means of attaining the competitiveness of regions.

Given the incidences of terrorism that have shocked Europe, all the regions should take on additional concerns over implementing security actions especially as while Portugal remains considered as a safe destination, the country is increasingly sought out by tourists from all around the world. Through this research, we verify how competitiveness does not constitute any easy task and especially as Portugal hosts regions with such varied and very specific characteristics. Thus, we hope that the results returned by this research project may establish the framework necessary to managers engaging in the development of strategic actions able to foster and nurture competitive advantages and attain the much sought after competitiveness. Porter (1990) duly posits how companies and not countries compete in international markets and hence the competitiveness of a nation or a region stems from the success its companies attain in international markets.

The major limitation of this study derives from the lack uniformity in the responses provided in regional terms. We would suggest future research applies a longitudinal study so as to enable the identification of trends in tourism competitiveness taking place in the respective regions.

\section{References}

Ahmed, Z. \& Krohn, F. (1990). Reversing the United States declining competitiveness in the marketing of international tourism: a perspective on future policy. Journal of Travel Research, 29(2), 23-29.

Alberti, F. \& Giusti, J. (2012). Cultural heritage, tourism and regional competitiveness: the motor valley cluster. City, Culture and Society, 3, 261-273.

Alberto, D. (2008). Modelos de desenvolvimento regional, in Leitão, J., Ferreira, J. \& Azevedo, S., Dimensões competitivas de Portugal contributos dos territórios, sectores, empresas e logística. Vila Nova de Famalicão: Centro Atlântico.

Albuquerque, M. \& Godinho, C. (2001). Turismo - diagnóstico prospectivo, GEPE - Gabinete de Estudos e Prospectiva Económica. Lisboa: Ministério da Economia.

Arbulú, W., Lozano, J. \& Rey-Maquiera, J. (2016). The challenges of municipal solid waste management systems provided by public-private partnerships in mature tourist destinations: the case of Mallorca. Waste Management, 51(May), 252-258.

Assaf, A. \& Tsionas, E. (2015). Incorporating destination quality into the measurement of tourism performance: a Bayesian approach. Tourism Management, 49(August), 58-71. 
Baker, M., Hayzelden, C. \& Sussmann, S. (1996). Can destination management systems provide competitive advantage? A discussion of the factors affecting the survival and success of destination management systems. Progress in Tourism and Hospitality Research, 2, 1-13.

Bălan, D., Balaure, V. \& Veghes, C. (2009). Travel and tourism competitiveness of the world's top tourism destinations: an exploratory assessment. Annales Universitatis Apulensis Series Oeconomica, 11(2), 979-987.

Beladi, H., Chao, C. Ee, M. \& Hollas, D. (2015). Medical tourism and health worker migration in developing countries. Economic Modelling, 46(April), 391-396.

Boo, S., Busser, J. \& Baloglu, S. (2009). A model of customer-based brand equity and its application to multiple destinations. Tourism Management, 30, 219-231.

Botha, C., Crompton, J. \& Kim, S. (1999). Developing a revised competitive position for Sun/Lost City, South Africa. Journal of Travel Research, 37(4), 341-352.

Botti, L., Camprubi, R. \& Torrès, O. (2008). Tourism and regional development: small bussinesses and social network for competitiveness, research entrepreneurship and small business XXII. Covilhã: Universidade da Beira Interior.

Buhalis, D. (2000). Marketing the competitive destination of the future. Tourism Management, 21(1), 97-116.

Cabugueira, A. (2005). A importância económica do turismo. Revista Turismo e Desenvolvimento, 2(2), 97-104.

Camisón, C. \& Forés (2015). Is tourism firm competitiveness driven by different internal or external specific factors? New emprirical evidence from Spain. Tourism Management, 477-499.

Campos, A., Mendes, J. \& Albino, J. (2006). Para uma cultura da qualidade total no destino turístico: métodos de diagnóstico e estratégias de desenvolvimento. Revista Turismo e Desenvolvimento, 5, 21-40.

Cao, Y., Wang, B., Zhang, J., Wang, L., Pan, et al. (2016), Lake macroinvertebrate assemblages and relationship with natural environment and tourism stress in Jiuzhaigou Natural Reserve, China. Ecological Indicators, 62(March), 182-190.

Carmichael, B. (2002). Global competitiveness and special events in cultural tourism: the example of the Barnes exhibit at the Art Gallery of Ontario, Toronto. The Canadian Geographer, 46(4), 310-325.

Casadesus-Masanell, R. \& Ricart, J. (2010). Competitiveness: business model reconfiguration for innovation and internationalization. Management Research: The Journal of the Iberoamerican Academy of Management, 8(2), 123-149.

Chao, C., Hazari, B., Laffargue, J., Sgro, P. \& Yu, E. (2005). Tourism, jobs, capital accumulation and economy: a dynamic analysis. Paris-Jourdan Science Economiques, Working Paper 2005-16.

Chon, K. \& Mayer, K. (1995). Destination competitiveness models in tourism and their application to Las Vegas. Journal of Tourism Systems and Quality Management, 1(2/3/4), 227-246.

Claveria, O. \& Poluzzi, A. (2016). Positioning and clustering of the world's top tourist destinations by means of dimensionality reduction techniques for categorical data. Journal of Destination Marketing \& Management, Available online 12 February 2016.

Croes, R. \& Kubickova, M. (2013). From potential to ability to compete: towards a performance - based tourism competitiveness index. Journal of Destination Marketing \& Management, 2, 146-154.

Cooke, P. \& Morgan, K. (1998). The associational economy: firms, regions and innovation. Oxford: OUP.

Costa, C., Rita, P. \& Águas, P. (2004). Tendências internacionais em turismo, 2a Edição. Lisboa: Grupo Lidel.

Cores, R. (2011). Measuring and explaining competitiveness in the context of small island destinations. Journal of Travel Research, 50(4), 431-442.

Cracolici, M. F. \& Nijkamp, P. (2009). The attractiveness and competitiveness of tourist destination: a study of Southern Italian regions. Tourism Management, 30(3), 336-344.
Croes, R. \& Kubickova, M. (2013). From potential to ability to compete: towards a performance - based tourism competitiveness index. Journal of Destination Marketing \& Management, 2, 146-154.

Crouch, G. \& Ritchie, J. (1999). Tourism, competitiveness, and societal prosperity. Journal of Business Research, 44, 137-152.

Desrochers, P. \& Sautet, F. (2004). Cluster-based economic strategy, facilitation policy and the market process. Review of Austrian Economics, 17(2-3), 233-245.

D'Hauteserre, A. (2000). Lessons in managed destination competitiveness: the case of Foxwoods Casino Resort. Tourism Management, 21(1), 23-32.

Dimoska, T. \& Trimcevb, B. (2012). Competitiveness strategies for supporting economic development of the touristic destination. Procedia- Social and Behavioral Sciences, 44, 279- 288.

Dominguez, M. (2001). competitividade e análise estratéxica do sector turístico: unha primeira aproximación á potential creación dun cluster institucional para a mellora competitiva da zona Rías Baixas, Tese Doutoramento, Universidade de Santiago de Compostela, Espanha.

Dwyer, L. \& Kim, C. (2003). Destination competitiveness: determinants and indicators. Current Issues in Tourism, 6(5), 369-414.

Dwyer, L., Forsyth, P. \& Rao, P. (2002). Destination price competitiveness: exchange rate changes versus domestic inflation. Journal of Travel Research, 40(Feb), 328-336.

Dwyer, L., Mellor, R., Livaic, Z., Edwards, D. \& Kim, C. (2004). Attributes of destination competiviveness: a factor analysis. Tourism Analysis, 9, 91-101.

Echtner, C. \& Ritchie, J. (2003). The meaning and measurement of destination image. The Journal of Tourism Studies, 14(1), 37-48.

ECLAC (2009). An econometric study of the determinants of tourism competitiveness in the Caribbean. Economic Commission for Latin America and the Caribbean, United Nations.

Enright, M. \& Newton, J. (2005). Determinants of tourism destination competitiveness in Asia Pacific: comprehensiveness and universality. Journal of Travel Research, 43(4), 339-350.

Estevão, C., Nunes, S. \& Ferreira, J. (2014). Fatores de competitividade no sector hoteleiro em portugal: aplicação do Diamante de Porter, in Serra, F., Afonso, C. \& Santos, José António C. (2014). TMS Conference Series (2014) - Abordagens Contemporâneas em Hotelaria $e$ Restauração, (pp. 5-20). Faro: Universidade do Algarve.

Estevão, C. \& Ferreira, J. (2015). A competitividade no sector do turismo: contributos, desafios e implicações. Editora Edioteque.

Faulkner, B., Oppermann, M. \& Fredline, E. (1999). Destination competitiveness: an exploratory examination of South Australia's core attractions. Journal of Vacation Marketing, 5(2), 125-39.

Evans, N. (2016). Sustainable competitive advantage in tourism organizations: a strategic model applying service dominant logic and tourism's defining characteristics. Tourism Management Perspectives, 18(April), 14-25.

Hair, J., Sarstedt, M., Ringle, C. \& Mena, J. (2012). An Assessment of the use of partial least squares structural eequation modeling in marketing research. Journal of the Academy of Marketing Science, 40(3), 414-433. Henseler, J., Ringle, C. \& Sinkovics, R. (2009). The use of partial least squares path modeling in international marketing. Advances in International Marketing, 20, 277-320.

Jackson, J. \& Murphy, P. (2002). Tourism destinations as clusters: analytical experiences from the new world. Tourism and Hospitality Research, 4(1), 36-52.

Jackson, J. (2006). Developing regional tourism in china: the potential for activating business clusters in a socialist market economy. Tourism Management, 27, 695-706.

Hudson, S., Ritchie, J. \& Timur, S. (2004). Measuring destination competitiveness: an empirical study of Canadian ski resorts. Tourism Hospitality Planning and Development, 1(1), 79-94. 
Keegan, S. \& Lucas, R. (2005). Hospitality to hostility: dealing with low response rates in postal surveys. International Journal of Hospitality Management, 24(2), 157-169.

Kim, C. \& Dwyer, L. (2003). Destination competitiveness and bilateral flows between Australia and Korea. Journal of Tourism Studies, 14(2), 54-67.

Komppula, R. 82014). The role of individual entrepreneurs in the development of competitiveness for a rural tourism destination - a case study. Tourism Management, 40(February), 361-371.

Kotler, P., Bowen, J. \& Markens, J. (2006). Marketing for hospitality and tourism. New Jersey: Pearson Prentice Hall International Edition.

Kozak, M. (2003). Measuring competitive destination performance: a study of Spain and Turkey. Journal of Travel and Tourism Marketing, 13(3), 83-110.

Law n. 33/2013 of 16 May.

Lucas, R. (1999): Survey research. In B. Brotherton (Ed.). The Handbook of Contemporary Hospitality Management Research, Chichester: Wiley. Malakauskaite, A. \& Navickas, V. (2010). The role of clusters in the formation process of tourism sector competitiveness: conceptual novelties. Economics and Management, 149-154.

Manhas, P., Kour, P., Bhagata, A. (2014). Silk Route in the light of circuit tourism: an avenue of tourism internationalization. Procedia - Social and Behavioral Sciences, 144(August), 143-150.

Mann, M. \& Byun, S. (2011). Accessing opportunities in apparel retail sectors in India: Porter's Diamond approach. Journal of Fashion Marketing and Management: An International Journal, 15(2), 194-210.

Mazanec, J. (1995). Competition among European tourist cities: a comparative analysis with multidimensional scaling and self-organizing maps. Tourism Economics, 1(3), 283-302.

Moon, H., Rugman, A. \& Verbeke, A. (1998). A generalized double diamond approach to the global competitiveness of Korea and Singapore. International Business Review, 7, 135-150.

Navickas, V. \& Malakauskaite A. (2009). The possibilities for the identification and evaluation of tourism sector competitiveness factors. The Economic Conditions of Enterprise Functioning, 1(61), 3744.

Omerzel, D. (2006). Competitiveness of Slovenia as a tourist destination. Managing Global Transitions, 4(2), 167-189.

Papatheodorou, A. (2002). Exploring competitiveness in Mediterranean resorts. Tourism Economics, 8(2), 133-150.

Pearce, D. (1997). Competitive destination analysis in Southeast Asia. Journal of Travel Research, 35(4), 16-25.

Plano Estratégico Nacional do Turismo (PENT) - Horizonte 2013-2015, aprovado pela Resolução do Conselho de Ministros n.o 53/2007, de 15 de fevereiro.

Phillips, P. \& Moutinho, L. (2014). Critical review of strategic planning research in hospitality and tourism. Annals of Tourism Research, 48(September), 96-120.

Pike, S. (2012). Destination positioning opportunities using personal values: elicited through the repertory test with laddering analysis. Tourism Management, 33(1), 100-107.

Porter, M. (1990). The competitive advantage of nations, New York, NY: Free Pass.

Porter, M. (1994). Construir as vantagens competitivas de Portugal, fórum para a competitividade, Lisboa: 1a Edição.

Porter, M. (2001). Clusters of innovation: regional foundations of u.s. competitiveness. Monitor Group. Council on Competitiveness.

Ringle, C., Wende, S. \& Becker, J. (2015). "SmartPLS 3." Boenningstedt: SmartPLS GmbH, http://www.smartpls.com.

Ritchie, J. \& Crouch, G. (2010). A model of destination competitiveness/sustainability: Brazilian perspectives. Brazilian Public Administration Review, 5(5), 1049-1066.

Rodrigues, A. (2003). A engenharia turística como factor de desenvolvimento regional: alguns conceitos e aplicações, Nova
Economia e Desenvolvimento Regional, Actas do IX Encontro Nacional da APDR, 1, 671-692.

Seetaram, N, Forsyth \& Dwyer, L. (2016). Measuring price elasticities of demand for outbound tourism using competitiveness indices. Annals of Tourism Research, 56(January), 65-79.

Sharpley, R. (2002). The challenges of economic diversification through tourism: the case of Abu Dhabi. International Journal Tourism Research, 4, 221-235.

Sinclair-Maragh, G. \& Gursoy, D. (2015). Imperialism and tourism: the case of developing island countries. Annals of Tourism Research, 50(January), 143-158.

Smit, A. (2010). The competitive advantage of nations: is Porter's Diamond frame-work a new theory that explains the international competitiveness of countries? Southern African Business Review, 14(1), 105-130.

Tang, Z. (2015). An integrated approach to evaluating the coupling coordination between tourism and the environment. Tourism Management, 46(February), 11-19.

Olmos, G. (2012). Hospitality competitiveness measurement system. Journal of Global Business and Technology, 2(8), 29-37.

Omerzel, D. (2006). Competitiveness of Slovenia as a tourist destination. Managing Global Transitions, 4(2), 167-189.

Osman, H., Johns, N. \& Lugosi, P. (2014). Commercial hospitality in destination experiences: McDonald's and tourists' consumption of space. Tourism Management, 42(June), 238-247.

Ozer, K., Latif, H., Sarusik, M. \& Ergun, O. (2012). International competitive advantage of Turkish tourism industry: a comperative analyse of Turkey and Spain by using the diamond model of M. Porter. Procedia - Social and Behavioral Sciences, 58, 1064-1076.

Rahayuningsih, T., Muntasib, E. \& Prasetyo, L. (2016). Nature based tourism resources assessment using geographic information system (GIS): case study in Bogor. Procedia Environmental Sciences, 33, 365-375.

Rodríguez, B., Molina, J., Pérez, F. \& Caballero, R. (2012). Interactive design of personalised tourism routes. Tourism Management, 33(4), 926-940.

Tirasattayapitak, S., Chaiyasain, C. \& Beeton, R. (2015). The impacts of nature-based adventure tourism on children in a Thai village. Tourism Management Perspectives, 15(July), 122-127.

Vila, T., Darcy, S. \& Elisa, A. (2015). Competing for the disability tourism market - a comparative exploration of the factors of accessible tourism competitiveness in Spain and Australia. Tourism Management, 47, 61-272.

Wang, Y. \& Krakover, S. (2008). Destination marketing: competition, cooperation or coopetition? International Journal of Contemporary Hospitality Management, 20(2), 126-141.

WTO, OECD, Uniteds Nation and Comission of the European Communities (2001). Tourism Satellite Account: recommended methodological framework, OECD Publishing.

UNWTO, World Tourism Organization (2015). Tourism highlights, 2015 Edition, accessed on 17/06/2016 in http://www.eunwto.org/doi/pdf/10.18111/9789284416899.

Zaman, K., Shahbaz, M., Loganathan, N. \& Raza, S. (2016). Tourism development, energy consumption and environmental Kuznets curve: trivariate analysis in the panel of developed and developing countries. Tourism Management, 54(June), 275-283.

Zhang, J. (2016). Weighing and realizing the environmental, economic and social goals of tourism development using an analytic network process-goal programming approach. Journal of Cleaner Production, 127(July), 262-273.

Received: 10 January 2017

Revisions required: 15 May 2017

Accepted: 26 October 2017 